\title{
Pembetinaan ikan betok, Anabas testudineus (Bloch, 1792) menggunakan larutan susu dan kedelai melalui perendaman larva
}

[Feminization of climbing perch, Anabas testudineus (Bloch, 1792) through larvae immersion milk solutions and soy milk]

\author{
Helmizuryani ${ }^{\bowtie}$, Boby Muslimin, Khusnul Khotimah \\ Program Studi Budidaya Perairan Fakultas Pertanian Universitas Muhammadiyah Palembang \\ Jalan Jendral A. Yani 13 Ulu Palembang
}

Diterima: 15 Oktober 2016; Disetujui: 21 Maret 2017

\begin{abstract}
Abstrak
Kemampuan ikan betok, Anabas testudineus (Bloch, 1792) untuk tumbuh secara efektif dapat dilakukan dengan pembetinaan menggunakan bahan aktif steroid alami yang berasal dari susu sapi melalui perendaman larva. Penelitian ini bertujuan untuk meningkatkan nisbah kelamin betina, sintasan, dan pertumbuhan larva ikan betok. Bahan uji pada penelitian ini adalah larva usia tujuh hari yang didapatkan dari hasil pemijahan induk dengan penyuntikan secara semi alami. Tempat pemeliharaan larva dilakukan di panti benih. Penentuan nisbah kelamin larva ikan dilakukan di laboratorium biologi dan pengamatan air diuji di Laboratorium Kimia Fakultas Pertanian Universitas Muhammadiyah Palembang dari bulan Maret sampai bulan Mei 2016. Perlakuan uji dilakukan dengan perendaman larva pada media, yaitu susu sapi (P1), susu kedelai (P2), dan campuran keduanya (P3). Masing-masing perlakuan direndam selama 10 jam dengan dosis perlakuan sebesar $2 \mathrm{ml} \mathrm{L}^{-1}$ dan larva sebanyak 50 ekor L ${ }^{-1}$ direndam pada stoples ukuran 10 liter. Setelah proses peren-

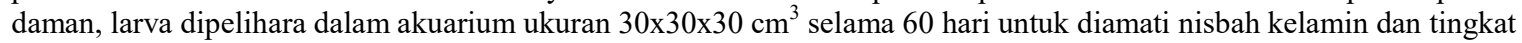
pertumbuhannya. Metode sampling yang digunakan adalah pengambilan sampel secara acak. Sampling pada ikan uji dan air diamati setiap 10 hari sekali dengan jumlah sampling sebanyak $40 \%$ pada ikan. Hasil penelitian menunjukkan perlakuan perendaman dengan larutan susu sapi adalah yang tertinggi, sintasan larva ikan betok sebesar $61,11 \%$, pertumbuhan panjang sebesar 3,77 cm, pertumbuhan bobot sebesar 1,69 g, dan nisbah kelamin betina sebesar 77,78\% .
\end{abstract}

Kata penting: ikan betok, pembetinaan, susu sapi dan kedelai, perendaman larva

\begin{abstract}
The ability of climbing perch, Anabas testudineus (Bloch, 1792) to grow effectively can be done for a sex reversal using natural steroids active ingredient which are derived from cow's milk through immersion of the fish larvae. This research aims to increase the ratio of the female sex, survival, and growth of the larvae of climbing perch. The research material is a juvenile of 7 days old which is gained from induce breeding methods. The research was conducted at a hatchery. Sex ratio was observed in biology laboratory and water quality was observed in chemical laboratory of the University of Muhammadiyah Palembang from March to May 2016. Post-larva was immersed with three media for the treatment i.e. cow's milk (P1), soya milk (P2) and the mix (P3). The immersion was done by 10 hours; used $2 \mathrm{ml} \mathrm{L}^{-1}$ dozed on each part and 50 post-larva were immersed on jar sized 10 liters. After immersing the post-larva was reared during 60 days in aquarium sized $30 \times 30 \times 30 \mathrm{~cm}^{3}$ for observation of sex ratio and growth. Sampling method used is a random sampling. The post-larva and water were observed every 10 days with $40 \%$ material sample of post-larva. The result showed that best grow is in $\mathrm{P} 1(61.11 \%)$. The length growth is $3.77 \mathrm{~cm}$, biomass growth is $1.69 \mathrm{~g}$, and produce sex ratio of female is $77.78 \%$.
\end{abstract}

Keywords: climbing perch, feminization, cow's milk and soya milk, immersion

\section{Pendahuluan}

Ikan betok, Anabas testudineus (Bloch, 1792) adalah spesies ikan asli Indonesia yang tersebar di beberapa perairan umum daratan di Pulau Kalimantan, Sumatera, dan Jawa. Ikan ini adalah salah satu jenis ikan penetap (blackfishes) yang umumnya hidup liar di perairan rawa,

Penulis korespondensi

Alamat surel: helmizuryani@gmail.com sungai, dan danau. Permintaan terhadap ikan betok ini cukup tinggi. Di Kalimantan ukuran konsumsi ikan betok memiliki harga antara $\mathrm{Rp}$ 30.000-45.000 kg-1 sedangkan di Sumatera harganya antara Rp 16.000-Rp 20.000 (Etika et al. 2013). Untuk memenuhi permintaan terhadap ikan tersebut nelayan hanya mengandalkan hasil tangkapan dari alam yang bersifat musiman. Kerusakan habitat, pengalihan fungsi lahan, eksploi- 
tasi berlebih, dan pembangunan waduk dapat menyebabkan penurunan populasi ikan bahkan dapat menyebabkan kepunahan spesies (Wargasasmita 2002, Sawitri \& Iskandar 2006). Melihat adanya kondisi ini, dikhawatirkan pada masa yang akan datang keberadaan ikan betok di Sumatera Selatan akan terancam. Pencegahan ikan ini dari kepunahan perlu dilakukan dengan upaya budi daya (Ross et al. 2008) agar produksi ikan betok dapat berlangsung secara berkelanjutan.

Teknik pengarahan kelamin (sex reversal) adalah rekayasa hormonal untuk mengubah karakter seksual betina ke jantan (penjantanan) atau dari jantan menjadi betina (pembetinaan) (Mardiana 2009). Pada penerapan teknologi ini ikan yang seharusnya berkelamin jantan diarahkan perkembangan gonadnya menjadi betina (pembetinaan) dan dari betina menjadi jantan (penjantanan). Hal ini bisa dilakukan karena gonad ikan ketika baru menetas belum berdiferensiasi secara jelas menjadi jantan atau betina (Zairin 2002). Salah satu cara untuk mengarahkan ikan berkelamin betina adalah menggunakan hormon estrogen, yaitu hormon estradiol-17ß yang merupakan salah satu hormon sintetik. Namun saat ini hormon sintetik dilarang pemakaiannya. Kementerian Kelautan dan Perikanan melarang penggunaan 21 jenis obat-obatan dalam kegiatan budi daya perikanan, salah satunya steroid sintetik estradiol -17ß (Kepmen No. 52/Kepmen-KP/2014 tentang klasifikasi obat ikan). Oleh karena itu perlu dilakukan kajian terhadap hormon alami dan bahan alami untuk menggantikan hormon sintetik, yaitu menggunakan susu sapi dan susu kedelai. Susu kedelai yang merupakan salah satu olahan dari bahan baku kedelai mengandung hormon fitoestrogen dari klas isoflavon yang dapat bekerja seperti hormon estrogen. Susu sapi adalah bahan makanan yang banyak mengandung estrogen alami.
Penggunaan susu sebagai bahan alami diharapkan dapat membantu pembetinaan ikan betok dengan tujuan memaksimalkan nisbah kelamin tunggal betina dan meningkatkan pertumbuhan saat budidaya.Hasil penelitian Hidayat et al. (2016) memperlihatkan bahwa pertumbuhan ikan betok atau papuyu berdasarkan jenis kelamin jantan dan betina yang dipelihara mulai dari benih sampai dewasa selama delapan bulan memiliki hasil tingkat pertumbuhan yang berbeda. Ikanbetina menunjukkan pertumbuhan bobot mutlak dan laju pertumbuhan harian ikan betina masing-masing 1,48 kali dan 1,17 kali lebih tinggi dibandingkan dengan ikan jantan. Tujuan penelitian ini adalah untuk meningkatkan nisbah kelamin larva ikan betok (Anabas testudineus, Bloch, 1972) kelamin tunggal betina menggunakan susu sapi dan susu kedele.

\section{Bahan dan metode}

Penelitian dilakukan di Laboratorium Basah Budidaya Perairan, Laboratorium Biologi dan Laboratorium Kimia Fakultas Pertanian Universitas Muhammadiyah Palembang dari bulan Maret sampai Mei 2016. Ikan uji yang digunakan adalah larva ikan betok yang berumur tujuh hari dengan bobot 0,01-0,02 $\mathrm{g} \mathrm{larva}^{-1}$. Induk yang matang gonad dipijahkan secara semi alami, yaitu dengan menyuntikkan ovaprim ke induk betina sebanyak $0,3 \mathrm{ml} \mathrm{kg}^{-1}$ dan induk jantan sebanyak $0,1 \mathrm{ml} \mathrm{kg}^{-1}$ di bawah pangkal sirip punggung kemudian dipasangkan antara jantan betina dengan perbandingan 1:2. Pemijahan berlangsung dua hari kemudian, selanjutnya induk jantan dan betina dipindahkan dari wadah penetasan.

Larva hasil penetasan setelah berumur tujuh hari direndam dalam perlakuan susu sapi, susu kedele, dan campuran susu sapi dan kedele selama 10 jam dengan dosis $2 \mathrm{ml} \mathrm{L}^{-1}$ air dalam stoples ukuran 10 liter dengan kepadatan 50 ekor. 
Setelah proses perendaman, larva dipelihara dalam akuarium ukuran $30 \times 30 \times 30 \mathrm{~cm}^{3}$ selama 60 hari dengan ketinggian air $20 \mathrm{~cm}$. Selama pemeliharaan ikan diberi pakan alami Artemia salina, kemudian cacing Tubifex, dan selanjutnya pelet dengan frekuensi tiga kali sehari (pagi, siang, dan sore). Penyiponan dan penggantian air sebesar $10 \%$ dari volume air akuarium dilakukan setiap 10 hari sekali.

Rancangan yang digunakan adalah rancangan acak lengkap, dengan tiga perlakuan dan tiga ulangan. Perlakuan P1: perendaman dengan larutan susu sapi, perlakuan P2: perendaman dengan larutan susu kedelai, dan perlakuan P3: perendaman dengan campuran larutan susu sapi dan susu kedelai.

Ikan diamati setiap hari untuk dilihat kematiannya dan dicatat. Pada akhir penelitian dihitung nilai sintasannya yaitu jumlah ikan yang masih hidup setelah waktu tertentu dengan menggunakan rumus (Effendi 2004).

$$
\mathrm{S}=\frac{N t}{N 0} \times 100
$$

Keterangan: $\mathrm{S}=\operatorname{sintasan}(\%), \mathrm{N}_{\mathrm{t}}=$ jumlah ikan yang masih hidup pada waktu t. $\mathrm{N}_{\mathrm{o}}=$ jumlah awal ikan uji.

Sampling dilakukan setiap 10 hari sekali untuk melihat pertumbuhan sebanyak 30\% atau 15 ekor pada setiap akuarium. Ikan uji ditimbang bobotnya menggunakan timbangan digital (ketelitian 0,1 g), dan diukur panjangnya menggunakan penggaris aluminium (ketelitian 0,1 cm). Menurut Effendi (2004), pertumbuhan dihitung dengan rumus:

$$
\begin{aligned}
\mathrm{W}_{\mathrm{m}} & =\mathrm{W}_{\mathrm{t}}-\mathrm{W}_{\mathrm{o}} \\
\mathrm{L}_{\mathrm{m}} & =\mathrm{L}_{\mathrm{t}}-\mathrm{L}_{\mathrm{o}}
\end{aligned}
$$

Keterangan: $\mathrm{W}_{\mathrm{m}}=$ pertumbuhan berat, $\mathrm{W}_{\mathrm{t}}=$ berat akhir ikan $(\mathrm{g}), \mathrm{W}_{\mathrm{o}}=$ berat awal ikan $(\mathrm{g}), \mathrm{L}_{\mathrm{m}}=$ pertumbuhan panjang, $\mathrm{L}_{\mathrm{t}}=$ panjang akhir ikan $(\mathrm{cm}), \mathrm{L}_{\mathrm{o}}=$ panjang awal ikan $(\mathrm{cm})$

Kualitas air media diukur sebagai data penunjang yang meliputi $\mathrm{pH}$, suhu, oksigen terlarut, dan ammonia. Suhu air diukur dengan termome- ter setiap hari, sedangkan oksigen terlarut diukur menggunakan $\mathrm{DO}$ meter, $\mathrm{pH}$ menggunakan $\mathrm{pH}$ meter, dan $\mathrm{NH}_{3}$ menggunakan spektrofotometer yang diukur setiap 10 hari sekali.

Jenis kelamin ikan ditentukan pada akhir penelitian saat ikan berumur 60 hari. Pemeriksaan gonad ikan uji dilakukan dengan metode asetokarmin (Zairin 2002). Larutan asetokarmin dibuat dengan cara melarutkan 0,6 g bubuk karmin dalam $100 \mathrm{ml}$ asam asetat 45\%. Larutan dididihkan dalam becker ukuran $300 \mathrm{ml}$ selama 2-4 menit kemudian didinginkan. Setelah dingin larutan disaring dengan kertas saring whatman size 40 mesh. Selanjutnya larutan dimasukkan kedalam botol tertutup dan disimpan pada suhu ruang $28^{\circ} \mathrm{C}$. Larutan asetokarmin ini berfungsi memperjelas/mempermudah pengamatan dengan menggunakan mikroskop.

Langkah selanjutnya adalah pengambilan gonad ikan sebagai sampel sejumlah 10\% dari total ikan uji. Gonad dihaluskan dan diletakkan di atas gelas obyek dan diberi larutan asetokarmin sebanyak dua tetes. Gelas obyek ditutup dengan gelas penutup. Gonad dalam bentuk preparat siap diamati dibawah mikroskop binokuler dengan pembesaran 40x dengan skala 0,0025 $\mu \mathrm{m}$. Gonad jantan berupa testis, sedangkan gonad betina berupa ovari. Ovari dicirikan bewarna merah muda, diisi butiran-butiran telur, berbentuk gel transparan seperti jaringan gonad lembut, menempati bagian posterior rongga badan, sedangkan testis bewarna keputih-putihan berisi sel sperma sangat halus, dan menempel pada rongga badan.

Data hasil pengamatan diproses dengan tabulasi dalam tabel rancangan acak lengkap dan dianalisis menggunakan uji F. Bila hasil analisis didapatkan nilai $\mathrm{F}$ hitung $<\mathrm{F}$ tabel (5\% dan $1 \%$ ), maka tidak dilakukan uji lanjutan, sedangkan bila $\mathrm{F}$ hitung $>\mathrm{F}$ tabel, maka dilakukan uji lanjutan 
berdasarkan koefisien keragaman. Nilai rataan sintasan, persentase nisbah kelamin yang dihasilkan ditampilkan dalam kurva atau histogram.

\section{Hasil}

Sintasan larva ikan betok selama penelitian disajikan pada Gambar 1. Sintasan larva ikan betok pada semua perlakuan yang dicobakan memberikan hasil yang berpengaruh tidak nyata, hal ini terlihat dari nilai $\mathrm{F}$ hitung $(0,64)$ lebih kecil daripada nilai $\mathrm{F}$ tabel $(5,14)$.
Hasil pengamatan pertumbuhan panjang dan bobot larva ikan betok selama penelitian disajikan pada Gambar 2 dan 3. Hasil analisis keragaman pada pengamatan pertumbuhan panjang larva ikan betok dari semua perlakuan perendaman susu memberikan hasil yang berpengaruh tidak nyata. Hal ini terlihat dari nilai $F$ hitung $(1,46)$ lebih kecil daripada nilai $\mathrm{F}$ tabel $(5,14)$. Pengamatan bobot ikan pada semua perlakuan perendaman susu memberikan hasil yang berpengaruh tidak nyata dengan nilai $\mathrm{F}$ hitung $(0,44)$ lebih kecil dari pada nilai $\mathrm{F}$ tabel $(5,14)$.

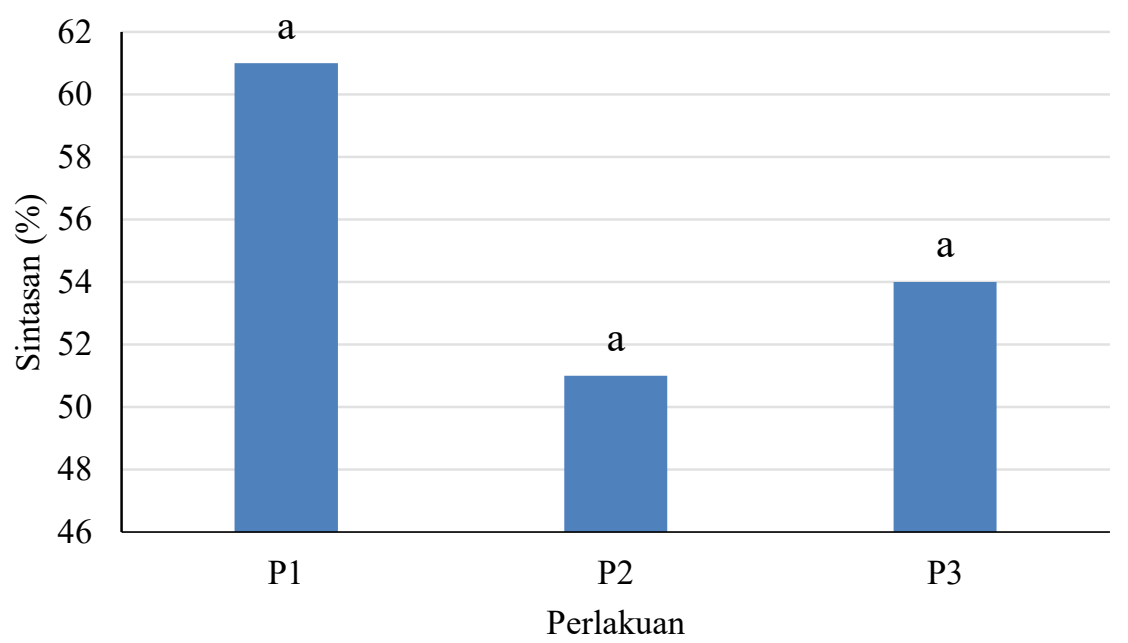

Gambar 1. Grafik rata-rata sintasan larva ikan betok selama penelitian

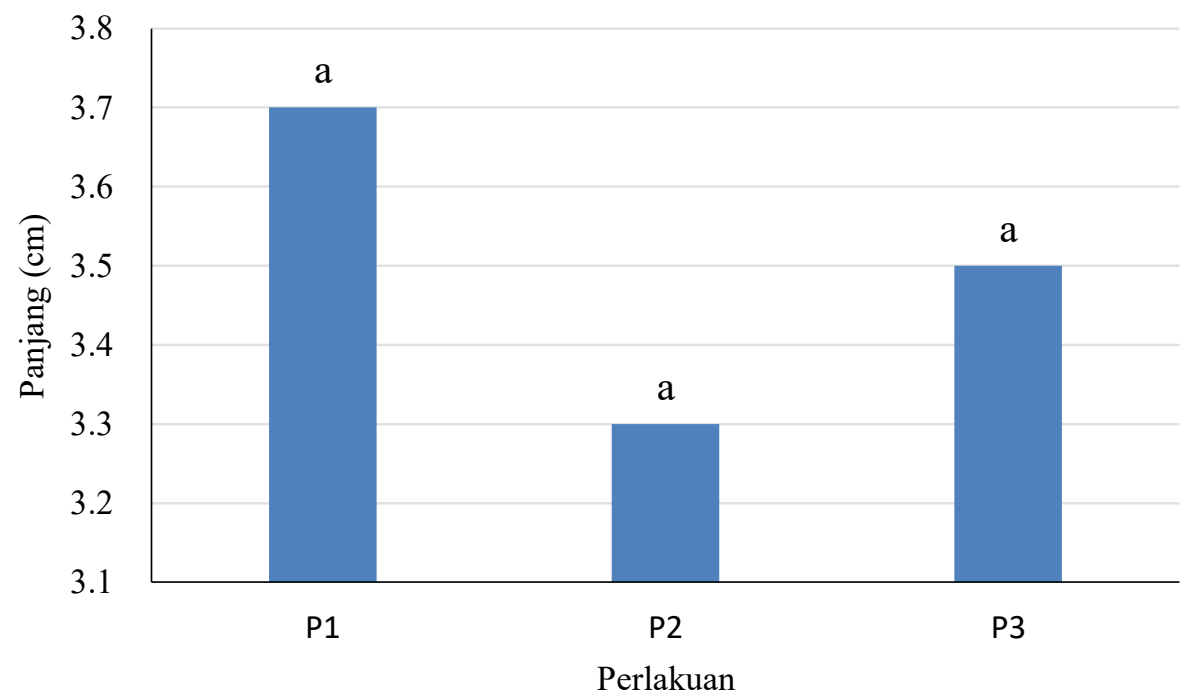

Gambar 2. Grafik rata-rata pertumbuhan panjang larva ikan betok selama penelitian 


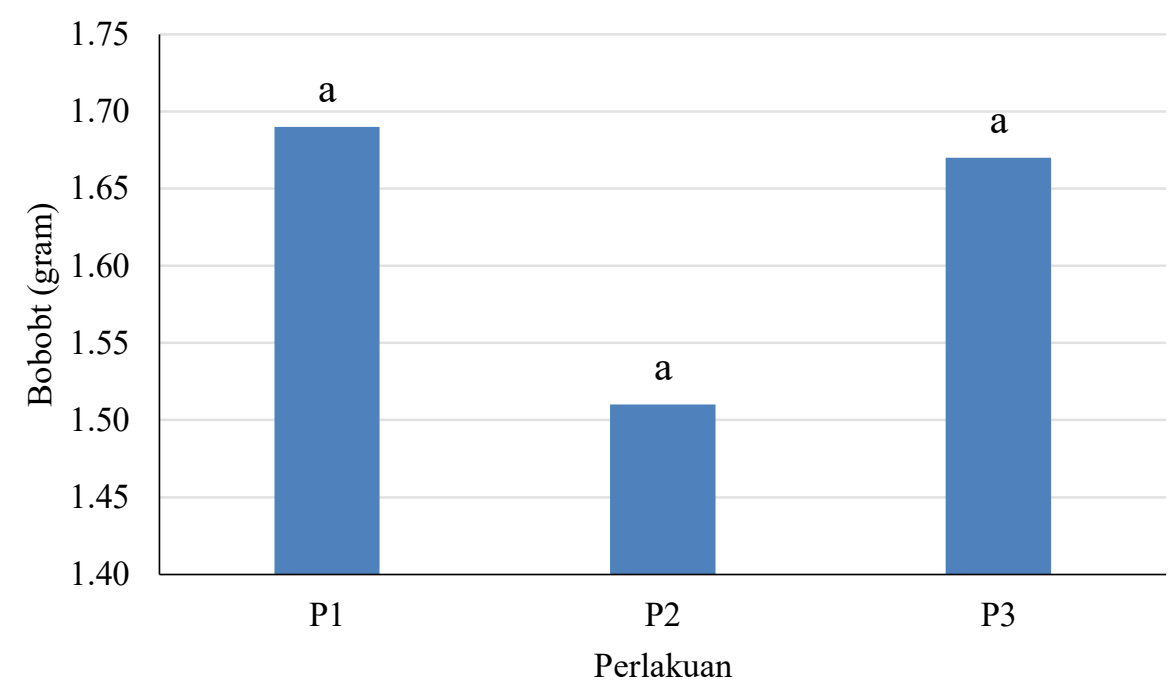

Gambar 3. Grafik rata-rata pertumbuhan bobot larva ikan betok selama penelitian

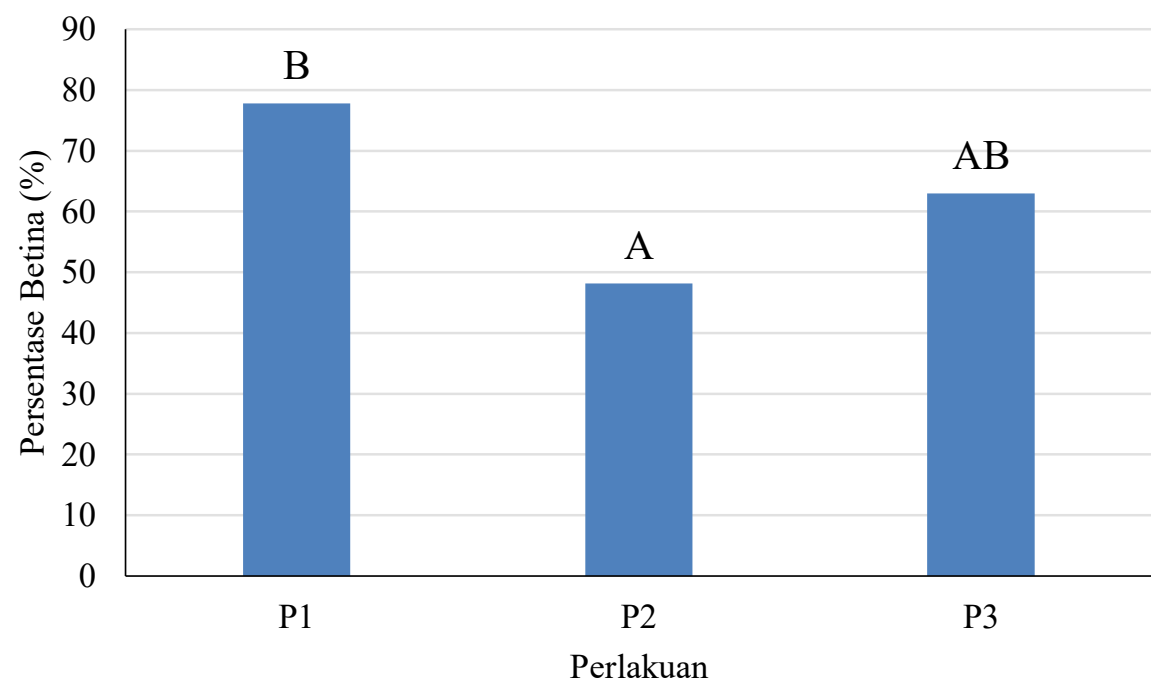

Gambar 4. Grafik nisbah kelamin betina larva ikan betok selama penelitian

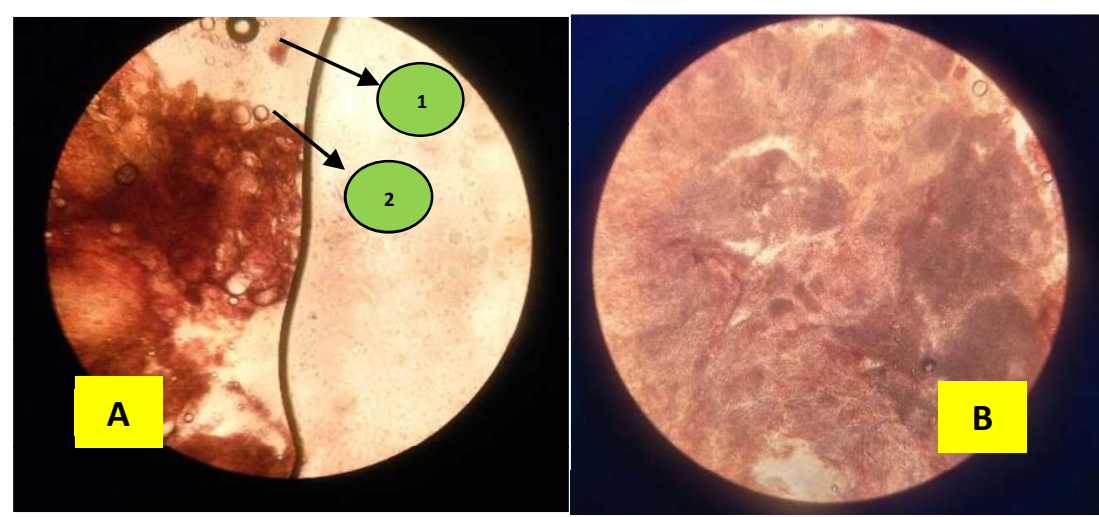

Gambar 5. Gambar gonad ikan betok (A) betina, (1) oogonia, (2) oosit (B) jantan 
Hasil analisis sidik ragam pada nisbah kelamin betina larva ikan betok pada taraf uji 5\% terlihat perbedaan yang nyata pada Gambar 4. Perlakuan perendaman dengan larutan susu sapi berbeda nyata terhadap perlakuan perendaman dengan susu kedele dan perlakuan perendaman dengan campuran susu sapi dan susu kedele.

Kualitas air selama penelitian dilakukan bernilai sebagai berikut: suhu berkisar antara 28$32^{\circ} \mathrm{C}, \mathrm{pH}$ sebesar $6,1-7,2$, oksigen terlarut berkisar antara 4,45-8,94 $\mathrm{mgL}^{-1}$, dan ammonia 0,0205$0,24 \mathrm{mgL}^{-1}$.

Hasil pengamatan gonad dengan mikroskop menunjukkan bahwa gonad betina dan jantan memiliki perbedaan (Gambar 5). Gonad ikan betina mempunyai sel telur yang berbentuk bundar yang di dalamnya terdapat inti sel. Gonad betina ikan betok berbentuk gel transparan seperti jaringan yang lembut berisikan butiran butiran telur. pewarnaan menggunakan asetokarmin terlihat sel telur berbentuk bulat dan terdapat inti sel bewarna pudar yang dikelilingi sitoplasma berwarna merah. Sebaliknya, pada gonad jantan tidak terlihat butiran telur, melainkan garis-garis halus yang terlihat menyebar dengan sel spermatozoa berupa titik halus menyebar (Hidayat 2016).

\section{Pembahasan}

Perendaman larva ikan betok umur 7 hari selama 10 jam dalam larutan susu tidak memberikan perbedaan yang nyata terhadap sintasan larva ikan betok. Hasil ini menunjukkan bahwa ke tiga jenis bahan perendaman larva tidak memberikan persentase sintasan larva betok yang berbeda jauh. Sintasan larva ikan betok selama penelitian berkisar antara 51,11-61,11\%. Sintasan larva ikan betok dipengaruhi oleh padat tebar, salinitas, dan pakan (Mahmood et al. 2004, Morioka et al. 2009, Chotipuntu \& Ayakul 2010, Jannat et al.
2012). Persentase sintasan pada penelitian ini tergolong tinggi untuk pemeliharaan larva. Hal ini terlihat dari hasil penelitian yang telah dilakukan oleh beberapa penelitian sebelumnya. Larva yang dipelihara pada skala laboratorium menghasilkan sintasan sebesar 17-54\% (Maidie et al. 2015), 38-55\% (Susila 2016), dan 30-50\% (Mahmood et al. 2004). Pada masa larva, ikan betok mengalami masa rentan, karena pada masa ini ikan betok memiliki sifat kanibal pada umur enam hari setelah menetas (Maidie et al. 2015) dan sejalan dengan pendapat Morioka et al. (2009) bahwa pada usia sepuluh hari pascatetas larva memiliki sifat kanibal dan pada usia lima hari setelah menetas larva sudah mulai ditumbuhi gigi, sehingga perlu adanya perkiraan padat tebar yang tepat selama masa pemeliharaan agar angka sintasan dapat menjadi baik. Selama pelaksanaan penelitian tidak ditemukan adanya jasad atau sisa tubuh ikan, namun terdapat beberapa ikan yang memiliki ukuran tubuh yang lebih lebih besar sehingga diperkirakan persentase sintasan yang rendah akibat adanya kanibalisme larva.

Padat tebar pada penelitian ini 50 ekor per akuarium dengan sintasan mencapai 61\%. Menurut Susila (2016), sintasan larva ikan betok dapat mencapai 55\% dengan padat tebar larva sebanyak 10 ekor $\mathrm{L}^{-1}$ dan mencapai $38 \%$ dengan padat tebar 30 ekor $\mathrm{L}^{-1}$, karena padat tebar pada larva dapat menyebabkan terjadinya stress sehingga respon terhadap pakan menurun dan juga rentan terhadap patogen.

Selain padat tebar, sintasan juga dipengaruhi oleh pakan. Hal ini dikarenakan sintasan dipengaruhi oleh selain ketersediaan pakan, juga penyesuaian jenis pakan. Pada penelitian ini pakan awal yang diberikan pada larva berupa Artemia salina, selanjutnya pada usia dua puluh hari diberikan pakan berupa cacing sutera. Kesesuaian pakan cacing sutera pada larva ikan sejalan 
dengan penelitian Mahmood et al. (2004) bahwa larva ikan betok yang diberikan cacing sutera memiliki persentase sintasan yang lebih baik yaitu sebesar 61\% dibandingkan dengan Artemia salina $(50 \%)$ dan rotifer (30\%).

Perlakuan perendaman berbagai jenis larutan susu berpengaruh tidak nyata terhadap pertumbuhan panjang dan bobot larva ikan betok. Salah satu faktor yang memengaruhi pertumbuhan adalah faktor eksternal, yaitu kondisi lingkungan dan pakan. Dalam penelitian ini, ikan betok diberi pakan alami berupa cacing sutera selama dua puluh hari dan dilanjutkan dengan pemberian pakan ikan berupa pellet. Pertumbuhan ikan dapat berkembang dengan baik bila diberi pakan cacing sutera, karena tingginya kandungan nutrisi pada cacing sutera yang terdiri atas $57 \%$ protein, 13,30\% lemak dan 2,04\% karbohidrat (Anggraini \& Nurlita 2013). Pakan pellet yang diberikan selama penelitian merupakan pakan buatan yang memiliki nilai protein sebesar 32\% sebagai sumber energi yang dibutuhkan. Hasil ini sependapat dengan Asyari (2007) bahwa makanan yang didapat oleh ikan digunakan untuk pergerakan, pemulihan organ tubuh yang rusak, dan selebihnya dimanfaatkan untuk pertumbuhan. Faktor ekternal lainnya adalah lingkungan, khususnya suhu. Pada penelitian ini suhu air yang diberlakukan skala laboratorium adalah $30^{\circ} \mathrm{C}$. Faktor suhu menurut Liana (2007), di derajat tersebut dapat meningkatkan aktivitas metabolisme tubuh ikan sehingga dapat meningkatkan nafsu makan ikan yang menghasilkan pertumbuhan yang baik.

Dari hasil sidik ragam nisbah kelamin betina larva ikan betok dengan perlakuan perendaman menggunakan bahan alami yaitu larutan susu sapi yang direndam selama 10 jam berpengaruh sangat nyata terhadap pembetinaan larva ikan betok karena kandungan estrogen pada susu sapi. Menurut Wedekind (2010), ikan yang terpapar estrogen dapat memengaruhi dan mengarahkan perubahan gonad ikan menjadi betina yang sebelumnya berjenis kelamin jantan, bahkan dapat menyebabkan kemandulan. Oleh karena itu diperlukan kisaran dosis yang tepat pada aplikasinya. Estrogen juga dapat membantu dalam percepatan bentuk vitelogenesis pada gonad ikan betina (Pinto et al. 2014). Estrogen pada larutan susu sapi memiliki nilai sebesar $0,093 \mathrm{mg} \mathrm{mL}^{-1}$, sedangkan pada estrogen sintetis $17 \beta$-estradiol sebesar 0,065 mg mL $\mathrm{mL}^{-1}$ (Grgurevic et al. 2016). Selain dosis diketahui masa efektif perendaman bahan estrogen. Umumnya perendaman dengan dosis yang tinggi membutuhkan waktu perendaman yang singkat dan sebaliknya.

Pemberian estrogen pada tahap awal ini berkaitan dengan stadia awal perkembangan larva ketika gonad berada dalam periode yang labil untuk dipengaruhi hormon dari luar. Akhir periode yang labil ini belum diketahui secara pasti sehingga diduga periode ini masih terjadi pada stadia larva. Terdapat beberapa jenis estrogen, yaitu a) natural animal estrogen, b) natural plant estrogenic, dan c) syntetic estrogenic (Pinto et al. 2014). Natural animal estrogen memiliki ikatan estrogen yang baik sehingga estrogen dapat berperan dalam pembentukan fisiologis reproduksi ikan dan mampu meningkatkan fungsi imun.

Pada stadia awal perkembangan gonad larva ikan, jenis kelamin belum terbentuk secara sempurna. Pada periode ini, gonad dapat diarahkan jenis kelaminnya menjadi jantan atau betina dengan bantuan hormon dari luar. Pemberian estrogen dapat membantu dalam pembentukan jenis kelamin betina.

Menurut Ariyanto et al. (2010), terdapat dua faktor yang berpengaruh terhadap diferensiasi atau pembentukan nisbah kelamin, yaitu faktor genetik secara internal dan faktor lingkungan se- 
cara eksternal. Umur organisme, waktu perendaman, dosis, dan temperatur adalah faktor-faktor yang dapat memengaruhi deferensiasi kelamin ikan (Ariyanto et al. 2010, Budd et al. 2015, Shao et al. 2017). Suhu sebagai faktor eksternal dapat berperan dalam proses diferensiasi kelamin. Pada penelitian Ariyanto et al. (2010), larva ikan nila dengan pemberian suhu $24^{\circ} \mathrm{C}$ memberikan jumlah ikan jantan yang lebih sedikit dibandingkan dengan pemberian suhu $25^{\circ} \mathrm{C}$ memiliki keberhasilan untuk pembentukan kelamin betina yang lebih baik. Rangkaian penelitian yang dilakukan oleh Budd et al. (2015) memberikan hasil yang berbeda, yakni ikan kakap (Lates calcarifer) diberi perlakuan dengan suhu $20^{\circ} \mathrm{C}$ memberikan persentase kelamin jantan sebesar $73 \%$ dan pada suhu $15^{\circ} \mathrm{C}$ menghasilkan persentase kelamin betina sebesar $77^{\circ} \mathrm{C}$, sedangkan pada ikan lidah (Cynoglossus semilaevis) yang diberikan perlakuan dengan suhu $20^{\circ} \mathrm{C}$ menghasilkan $73 \%$ ikan berkelamin betina. Bila dibandingkan dengan penelitian ini, pemberian suhu antara 28$32^{\circ} \mathrm{C}$ menghasilkan nisbah kelamin betina sebesar $77,78 \%$. Perbedaan ini disebabkan adanya kemampuan thermosensitivitas yang berbedabeda pada ikan karena faktor genetik dalam pembentukan organ tubuh, khususnya pada pembentukan gonad (Budd et al. 2015).

Pada saat ikan betok memasuki usia 30 hari pascatetas, pengamatan jenis kelamin telah dapat dilakukan (Kwon et al. 2000). Proses awal pembentukan jenis kelamin terjadi pada saat larva berumur 6-14 hari (Yuniarti et al. 2007). Selama proses pembentukan kelamin, ikan akan dipengaruhi oleh beberapa faktor, yaitu umur dan ukuran, lama perlakuan, dan lingkungan (Phelps et al. 2001), spesies ikan, genetik, tipe hormon, dosis hormon, dan waktu perlakuan (Dunham 2004). Agar proses pembentukan kelamin ikan betok dapat utuh, maka diperlukan penelitian lanjutan pada masa yang akan datang mengenai kualitas estrogen alami, interaksi estrogen alami terhadap sebagai pembentukan imun, faktor internal seperti ukuran ikan, dan faktor eksternal seperti temperatur.

\section{Kesimpulan}

Nisbah kelamin betina tertinggi terdapat pada perlakuan perendaman dengan larutan susu sapi sebesar 77,78\% sedangkan yang terendah pada perlakuan perendaman dengan larutan susu kedelai $48,15 \%$.

\section{Persantunan}

Penulis menyampaikan terima kasih yang setulus-tulusnya kepada Direktorat Jenderal Pendidikan Tinggi yang telah membiayai penelitian ini, Ketua Koordinasi Perguruan Tinggi Swasta Wilayah 2 Sumatera bagian Selatan. Rektor Universitas Muhammadiyah Palembang yang telah memberikan izin pelaksanaan penelitian ini, Kepala Lembaga Penelitian dan Pengabdian pada Masyarakat Universitas Muhammadiyah Palembang yang telah memfasilitasi penelitian ini, Ibu Dekan Fakultas Pertanian Universitas Muhammadiyah Palembang yang telah memberikan semangat dan dukungan sehingga selesainya penelitian, dan semua pihak yang telah ikut membantu dalam penyelesaian penelitian.

\section{Daftar pustaka}

Anggraeni NM, Nurlita A. 2013. Pengaruh pemberian pakan alami dan pakan buatan terhadap pertumbuhan ikan betutu (Oxyeleotris marmorata) pada skala laboratorium. Jurnal Seni Pomits, 2(1): 2337-3520.

Ariyanto D, Sumantadinata K, Sudrajat AO 2010. Diferensiasi kelamin tiga genotip ikan nila yang diberi bahan aromatase inhibitor. Jurnal Riset Akuakultur, 5(2): 165-174. 
Asyari. 2007. Pentingnya labirin bagi ikan rawa. Bawal: Widya Riset Perrikanan Tangkap, 1(5): 161-167.

Budd AM, Banh QQ, DOmingos JA, Jerry DR. 2015. Sex control in fish: approaches, challenges and opportunities for aquaculture. Journal of Marine Science Engineering, 3(2): 329-355.

Chotipuntu P, Avakul P. 2010. Aquaculture potential of climbing perch, Anabas testudineus in brackish water. Journal of Science and Technology, 7(1): 15-21.

Dunham RA. 2004. Aquaculture and Fisheries Biotechnology: Genetic Approaches. CABI Publ. Cambridge, USA. 357 p.

Effendi I. 2004. Pengantar Akuakultur. Penerbit Swadaya. Jakarta. $188 \mathrm{hlm}$.

Etika D, Muslim, Yulisman. 2013. Perkembangan diameter telur ikan betok (Anabas testudineus) yang diberi pakan diperkaya vitamin E dengan dosis berbeda. Jurnal Perikanan dan Kelautan, 18(2): 26-36.

Grgurevic N, Koracin J, Maidic G, Snoi T. 2016. Effect of diary estrogens from bovine milk on blood hormone levels and reproductive organs in mice. Journal of Diary Science, 99(8): $1-9$.

Hemizuryani, Muslimin B, Yusnita (Editor). 2015. Prosiding Seminar Nasional Sains dan Teknologi VI. Lampung, 3 November 2015. Lembaga Penelitian dan Pengabdian kepada Masyarakat Universitas Lampung. pp. 607-622.

Hidayat, Carman O, Alumuddin. 2016. Perbedaan pertumbuhan ikan papuyu Anabas testudineus jantan dan betina. Jurnal Akuakultur Indonesia, 15(1): 8-14.

Jannat MK, Rahman MM, Bashar Md.N, Ahmed F, Hossain Md.Y. 2012. Effects of stocking density on survival, growth and production of Thai climbing perch (Anabas testudineus) under fed ponds. Journal of Sains Malaysiana, 41(10): 1205-1210.

Liana YP. 2007. Efektivitas aromatase inhibitor yang diberikan melalui pakan buatan terhadap sex reversal ikan nila merah Oreochromis sp. Jurnal Sumberdaya Perairan, 2(1):1-7.

Kwon YJ, Haghpanah V, Kongson-Hurtado ML, Mc Andrew JB, Penman JD. 2000. Masculinization of genetic female nile tilapia (Oreochromis niloticus) by dietary admi- nistration of an aromatase inhibitor during sexual differentiation. The Journal of Experimental Zoology, 287(1): 46-53.

Maidie A, Sumoharjo, Asra SW, Ramadhan M, Hidayanto DN. 2015. Pengembangan pembenihan ikan betok (Anabas testudineus) untuk skala rumah tangga. Media Akuakultur, 10(1): 31-37.

Mahmood SU, Ali MS, Anwar UM. 2004. Effect of different feed in larval/fry rearing of climbing perch, Anabas testudineus (Bloch) in Bangladesh: II. Growth and survival. Pakistan Journal of Zoology, 36(1): 13-19.

Mardiana TY. 2009. Teknologi pengarahan kelamin ikan menggunakan madu. Pena Akuatika Jurnal Ilmiah Perikanan dan Kelautan, 1(1): 37-43

Morioka S, Ito S, Kitamura S, Vongvichith B. 2009. Growth and morphological development of laboratory-reared larval and juvenile climbing perch, Anabas testudineus. Ichthyological Research, 56(2): 162-171.

Pinto PIS, Estevao MD, Power DM. Effects of estrogen and estrogenic -disrupting compounds in fish mineralized. Marine Drugs, 12(8): 4474-4494.

Phelps RP, Sanchez WC, Couturier GM; Abiado M, Dabrowski K. 2001. Studies on fate of methyltestosteron and its metabolism in tilapia and on the use of phytochemicals as an alternative method to produce a monosex population of tilapia.Twenty-First Annual Technical Report. Aquaculture CRSP, Oregon State University, Cprvallis, Oregon, pp. 53-60

Ross LG, Carlos AMP, Ernesto JM. 2008. Developing native fish species for aquaculture : the interacting demands of biodiversity, sustainable aquaculture and livelihoods. Aquaculture Research, 39(7): 675-683.

Rutten MJM. 2005. Breeding for improved production of tilapia. Thesis. Wageningen. University of Wageningen. Netherland. $122 \mathrm{p}$.

Sawitri R, Iskandar S. 2006. Pengaruh pengelolaan hutan produksi terhadap keragaman Jenis plasma nutfah perairan. Jurnal Plasma Nutfah, 12 (2): 76-82.

Shao C, Li A, Chen S, Zhang P, Lian J, Hu Q, Sun B, Jin L, Liu S, Wang Z. 2017. Epigenetic modification and ingeritance in sexu- 
al reversal of fish. Journal of Genom Research, 24(4): 604-615.

Susila N. 2016. Pengaruh padat penebaran terhadap kelangsungan hidup larva ikan betok (Anabas testudineus) yang dipelihara dalam baskom. Jurnal Ilmu Hewan Tropika, 5(2): 72-75.

Wargasasmita, S. 2002. Ikan air tawar endemik Sumatera yang terancam punah. Jurnal Iktiologi Indonesia, 2(2): 41-49.
Wedekind C. 2010. Fish populations surviving estrogen pollution. Bio Medical Central Biology, 12(10): 1-3.

Yuniarti T, Hanif S, Prayoga T, Suroso. 2007. Teknik produksi induk betina ikan nila. Jurnal Budidaya Air Tawar, 4 (1): 32-36.

Zairin Jr. M. 2002. Sex Reversal: Memproduksi Benih Ikan Jantan atau Betina. Penebar Swadaya. Jakarta. $96 \mathrm{hlm}$. 